\title{
S100ß and fibroblast growth factor-2 are present in cultured Schwann cells and may exert paracrine actions on the peripheral nerve injury ${ }^{1}$
}

\author{
S100ß e fator de crescimento de fibroblasto-2 estão presentes nas células de Schwann \\ cultivadas e exercem ações parácrinas na lesão do nervo
}

\author{
Tatiana Duobles', Thais de Sousa Lima', Beatriz de Freitas Azevedo Levy", Gerson Chadi"I \\ ${ }^{\text {I }}$ Fellow of Department of Neurology, University of São Paulo School of Medicine, São Paulo, Brazil \\ ${ }^{\text {II }}$ Fellow Master degree of Neuroscience and Behavior, Psychology Institute, University of São Paulo, São Paulo, Brazil \\ III MD, PhD, Full Professor, Experimental Neurology, Department of Neurology, University of São Paulo School of Medicine, São Paulo, Brazil
}

\begin{abstract}
Purpose: The neurotrophic factor fibroblast growth factor-2 (FGF-2, bFGF) and $\mathrm{Ca}^{++}$binding protein S100ß are expressed by the Schwann cells of the peripheral nerves and by the satellite cells of the dorsal root ganglia (DRG). Recent studies have pointed out the importance of the molecules in the paracrine mechanisms related to neuronal maintenance and plasticity of lesioned motor and sensory peripheral neurons. Moreover, cultured Schwann cells have been employed experimentally in the treatment of central nervous system lesions, in special the spinal cord injury, a procedure that triggers an enhanced sensorymotor function. Those cells have been proposed to repair long gap nerve injury. Methods: Here we used double labeling immunohistochemistry and Western blot to better characterize in vitro and in vivo the presence of the proteins in the Schwann cells and in the satellite cells of the DRG as well as their regulation in those cells after a crush of the rat sciatic nerve. Results: FGF-2 and S100ß are present in the Schwann cells of the sciatic nerve and in the satellite cells of the DRG. S100ß positive satellite cells showed increased size of the axotomized DRG and possessed elevated amount of FGF-2 immunoreactivity. Reactive satellite cells with increased FGF-2 labeling formed a ring-like structure surrounding DRG neuronal cell bodies.Reactive S100ß positive Schwann cells of proximal stump of axotomized sciatic nerve also expressed higher amounts of FGF-2. Conclusion: Reactive peripheral glial cells synthesizing FGF-2 and S100ß may be important in wound repair and restorative events in the lesioned peripheral nerves.
\end{abstract}

Key words: Dorsal root ganglia. FGF-2. S-100ß. Paracrine action. Satellite cells. Sciatic nerve axotomy.

\section{RESUMO}

Objetivo: O fator neurotrófico fator de crescimento de fibroblastos-2 (FGF-2, bFGF) e a proteína ligante de Ca ${ }^{++}$S100ß são expressos pelas células de Schwann dos nervos e por células satélites do gânglio da raiz dorsal (GRD). Estudos recentes indicam a importância das moléculas nos mecanismos parácrinos relacionados à manutenção neuronal e à plasticidade de neurônios periféricos motores e sensoriais. Além disso, células de Schwann cultivadas têm sido empregadas experimentalmente no tratamento de lesões no sistema nervo central, especialmente na lesão da medula espinal, a qual mostrou uma melhora da função sensoriomotora. Estas células são ainda propostas no reparo do nervo lesado com perda de tecido. Métodos: Usamos a dupla marcação imunohistoquímica e o Western blot para caracterizar melhor in vitro e in vivo a presença das proteínas nas células de Schwann e nas células satélites do GRD assim como sua regulação nessas células após a compressão do nervo ciático de ratos. Resultados: FGF-2 e S100ß estão presentes nas células de Schwann do nervo ciático e nas células satélites do GRD. Células satélites do GRD axotomizado positivas para S100ß possuíam quantidade aumentada de imurreatividade da FGF-2. Células satélites reativas apresentando maior quantidade de FGF-2 formaram um anel ao redor dos corpos neuronais do GRD. Células de Schwann do coto proximal à axotomia do nervo ciático e positivas para S100ß também expressaram quantidades aumentadas de FGF-2. Conclusão: As células gliais periféricas ao sintetizar FGF-2 e S100ß podem ser importantes no reparo de cicatrização e em eventos restaurativos nas lesões do nervo.

Descritores: Gânglio da raiz dorsal. FGF-2. S-100ß. Ação parácrina. Células satélites. Axotomia do nervo ciático.

${ }^{1}$ Research performed at Neuroregeneration Center (LIM 45), Department of Neurology, University of São Paulo School of Medicine, University of São Paulo, São Paulo, Brazil 


\section{Introduction}

Satellite and Schwann cells, type of peripheral glia, surround neuronal cell bodies (sensory ganglia) and fibers (sensory and motor neurons) in the peripheral nervous system, providing physical and chemical supports for neurons. Those cells react after axotomy indicating their importance in the wound repair and regeneration ${ }^{1}$. In fact, interactions of sensory neurons and satellite cells as well as motor neurons and Schwann cells have been described during the development, and in the events of neuroplasticity related to nerve regeneration ${ }^{2}$.

Fibroblast growth factor-2 (FGF-2, bFGF), a neurotrophic factor member of heparin-binding growth factor family, and the $\mathrm{S} 100 ß, \mathrm{C} \mathrm{Ca}^{+2}$ binding protein ${ }^{3,4}$, seem to exert neurotrophic effects to peripheral sensory and motor neurons ${ }^{5}$ and can be up-regulated in dorsal root ganglia (DRG) after axotomy $y^{6,7}$.

The actions of glial neurotrophic factors such as FGF-2 and $\mathrm{S} 100 ß$ have been described to central neurons and also investigated recently in the peripheral nervous system ${ }^{8-10}$. Despite the presence of $\mathrm{S} 100 ß$ in the satellite glial cells of the DRG and in the Schwann cells of the sciatic nerves, the cellular change the $\mathrm{S} 100$ ß in those cells of axotomized sensory ganglia is still a material of a detailed investigation.

The ability of Schwann cells to trigger neuronal regeneration in the peripheral nervous system has been recently applied to promote neuronal restoration in the central nervous system $^{11}$. In fact, cultured Schwann cells from sciatic nerve has been employed in the spinal cord regeneration experimentally ${ }^{12}$, rising the necessity of a more detailed analysis on the presence of neurotrophic molecules in those cells in vitro and in vivo.

In the present study, the presence of FGF-2 and S100ß has been analyzed in cultured Schwann cells as well as in the normal and axotomized DRG and sciatic nerve of the rat, by means of Western blot and immunocytochemical analyses.

\section{Methods}

Specific pathogen-free adult male Wistar rats [body weight (b.w.) $200 \mathrm{~g}, \mathrm{n}=8$ ] from the University of São Paulo were kept under controlled temperature and humidity conditions with a standardized light-dark cycle (lights on at 7.00 a.m. and off at 7.00 p.m.) and free access to food pellets and tap water. The study was conducted under protocols approved by the Animal Care and Use Ethic Committee at University of São Paulo and in accordance with the Guide for the Care and Use of Laboratory Animals.

\section{Schwann cell culture}

Pure cultures of Schwann cells were obtained from sciatic nerves explants of adult Wistar rats as described previously ${ }^{13}$. Briefly, animals were deeply anaesthetized with sodium pentobarbital $3 \%(100 \mathrm{mg} / \mathrm{kg}$, ip) and sciatic nerves were dissected under sterile conditions, placed in $60 \mathrm{~mm}$ dishes containing Leibovitz-15 medium (L-15; Gibco, Grand Island, NY), and divested of their epineurial sheaths. Nerves were chopped into $1 \mathrm{~mm}^{2}$ pieces and transferred to $35 \mathrm{~mm}$ dishes containing DMEM (Gibco) supplemented with 10\% fetal bovine serum (FBS; Hyclone Laboratories, Logan, UT), $50 \mathrm{mg} / \mathrm{ml}$ gentamycin (DMEM-10; Gibco, NY). Nerve pieces were transferred to another $35 \mathrm{~mm}$ dish every week for 5 weeks and were fed twice a week. After five transfers, explants were devoid of fibroblasts and contained only Schwann cells. Explants were replated onto $35 \mathrm{~mm}$ dishes with $1.25 \mathrm{U} / \mathrm{ml}$ dispase (Boehringer Mannheim, Mannheim, Germany), $0.05 \%$ collagenase (Worthington, Freehold, NJ), and 15\% FBS in DMEM and were incubated at $37^{\circ} \mathrm{C}$ in $6 \% \mathrm{CO}_{2}$ overnight. After incubation, explants were washed with DMEM-10 and dissociated, and the SC were seeded onto poly-L-lysine-coated $100 \mathrm{~mm}$ dishes at a density of $2-3 \times 10^{6}$ cells/dish. After 24 hours, the culture medium was changed to DMEM-10 supplemented with $2 \mathrm{mM}$ forskolin (Sigma, St.Louis, MO) and $20 \mathrm{mg} / \mathrm{ml}$ pituitary extract (Gibco). Cells, fed twice a week with that medium, were allowed to expand until confluence. The purified SC were suspended in culture medium to yield a final density of $10^{6}$ cells $/ \mathrm{ml}$.

\section{Immunocytochemistry}

Schwann cell cultures were rinsed 2 times with phosphate buffered saline (PBS), and then fixed in paraformaldeyde (30min, at $4^{\circ} \mathrm{C}$ ). Sequential incubation of the fixed cells then took place at room temperature in: (1) wash in PBS for $5 \mathrm{~min}$ in agitation; (2) wash in PBS with $1 \%$ Triton for $10 \mathrm{~min}$; (3) wash in PBS with $0.02 \%$ Tween 20 (BioRad) for 5min; (4) wash in PBS with $0.02 \%$ Tween 20 and 1\% BSA (Sigma) for 5min; (5) block in PBS with $2 \%$ normal goat serum (NGS), $4 \%$ BSA, $0.2 \%$ Triton (Sigma) for 30min; (6) primary antibody incubation: using policlonal S-100 (Dako) or FGF-2 (Sigma) at 1:100 dilution in 2\% NGS, 4\% BSA, $0.2 \%$ Triton in PBS overnight. (7) Wash 3 times with PBS; (8) secondary antibody incubation with biotinylated anti-rabbit IgG (Vector Laboratories) at 1:250 dilution in PBS with $0.2 \%$ Triton, $1 \%$ NGS, 2\% BSA for 2 hours; (9) wash 3 times with cold PBS; (10) Incubation with Avidin-Biotin at 1:125 dilution in PBS; (11) wash again 3 times with PBS; (12) DAB reaction until color observation. The reaction was made in $0.01 \% \mathrm{H}_{2} \mathrm{O}_{2}, 0.5 \mathrm{mg} \mathrm{DAB} / \mathrm{ml}$. DAB labeled cultures were washed 3 times with distillated water, and the reaction was interrupted with Trizma.

\section{Western blot analysis of cultured Schwann cells}

Schwann cell FGF-2 and S100ß proteins were assessed by Western blot analysis ${ }^{14}$. The Schwann cells cultures were homogenized in PBS, pH 7.4, containing 1\% NP40, 0.5\% sodium deoxycholate, $1 \%$ sodium dodecyl sulfate, $1 \mathrm{mM}$ ethylenediaminetetraacetic acid, $1 \mathrm{mM}$ ethylene glycol tetraacetic acid, and 1\% protease inhibitor cocktail (Sigma). After centrifugation at $14,000 \mathrm{rpm}$ for $20 \mathrm{~min}$, the supernatants were transferred into new tubes and stored at $-70^{\circ} \mathrm{C}$ until use. Protein concentrations were determined. The samples were separated on a sodium dodecyl sulfate-polyacrylamide gel electrophoresis $(30 \mu \mathrm{g}$ of protein/lane) using a $12 \%$ Tris- $\mathrm{HCl}$ ready gel (Bio-Rad, California, USA) at $100 \mathrm{~V}$ for $1 \mathrm{~h}$. Proteins were transferred to nitrocellulose membrane for $1 \mathrm{~h}$ at $100 \mathrm{~V}$. After $1 \mathrm{~h}$ blocking with $5 \%$ milk in Tris-buffered saline $0.05 \%$ Tween 20 (TBS-T). Membranes were incubated overnight with rabbit polyclonal antibodies to bovine FGF-2 (residues 1-24) (1:1,000, Sigma, USA) or to S100ß protein (1:250, Dako, Denmark). The antisera were diluted in 3\% milk/TBS-T. Membranes were washed 2 times for 10 minutes in TBS-T and incubated at room temperature for $1 \mathrm{~h}$ with anti-rabbit $(1: 10,000$, Amersham, USA, diluted as described above) IgG-ECL conjugated 
secondary antibody. Blots were washed two times with TBS-T and once in TBS. After final washes, the membrane was incubated with Western Lightning Chemiluminescence Reagent Plus (PerkinElmer Life Science, USA) for 1 minute. The membranes were exposed to an X-ray film for imaging (HyperfilmTM ECL, Amersham Biosciences, USA) to visualize protein bands.

\section{Animals treatment}

Rats ( $n=5)$ were anaesthetized with sodium pentobarbital $3 \%$ (38 mg/kg, ip) and submitted to an unilateral crush (Figure 1) of the sciatic nerve as described elsewhere ${ }^{15}$. The proximal stump of the sciatic nerve was studied and contralateral unoperated side was used as control. Seven days after surgery, the rats were deeply anesthetized and killed by a transcardiac perfusion through a cannula inserted in the ascending aorta with $50 \mathrm{ml}$ of isotonic saline at room temperature followed by $350 \mathrm{ml}$ (rats) of fixation fluid $\left(4^{\circ} \mathrm{C}\right)$ over $6 \mathrm{~min}$. The fixative consisted of $4 \%(\mathrm{w} / \mathrm{v})$ paraformaldehyde and $0.2 \%(\mathrm{v} / \mathrm{v})$ picric acid in $0.1 \mathrm{M}$ phosphate buffer ( $\mathrm{pH}$ 6.9). The tissues were then rinsed in $10 \%$ sucrose (Merck, Germany) in $0.1 \mathrm{M}$ phosphate buffered saline, pH 7.4 (PBS) for $48 \mathrm{~h}$, frozen in dry ice-cooled $\left(-40^{\circ} \mathrm{C}\right)$ isopentane (Sigma, U.S.A) and stored at $-70^{\circ} \mathrm{C}$ freezer until use for immunohistochemical experiments as described bellow.

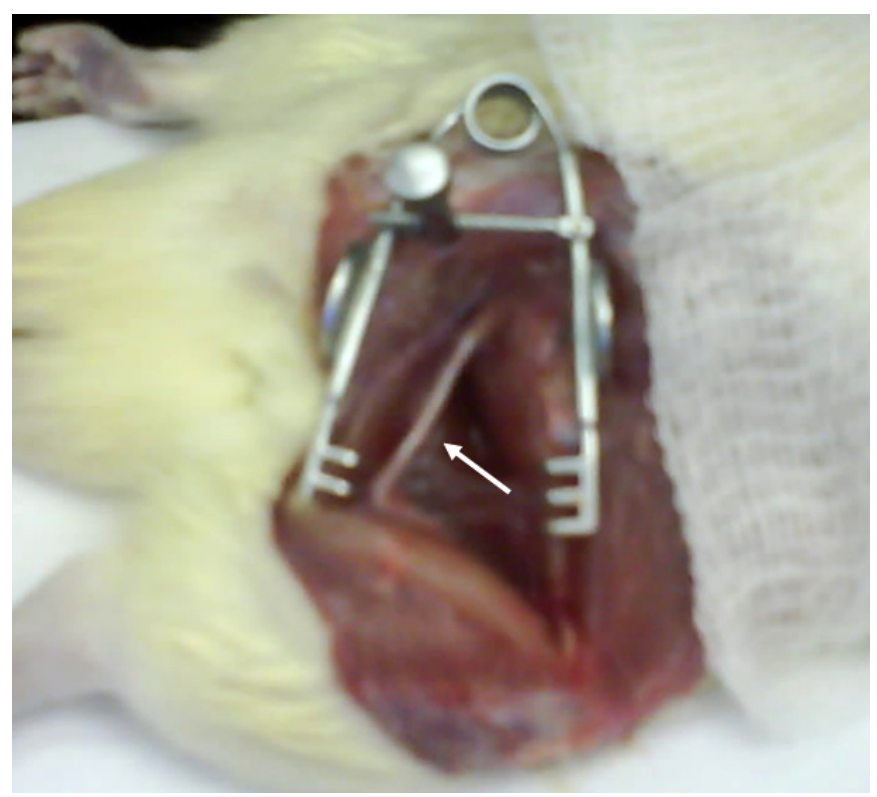

FIGURE 1 - Photograph of the microneurosurgery procedure showing a unilateral exposition of the rat sciatic nerve and the point where a crush lesion was applied (arrow).

Immunohistochemical procedures of the sciatic nerve and

$D R G$

Adjacent serial thaw-mounted $14 \mu \mathrm{m}$ sections were obtained with a cryostat (Leica, CM 3000, Germany) from the entire DRG and sciatic nerve fragments, bilaterally, of the rats. The sections were sampled systematically during sectioning. Seven series were obtained, including every seventh section.
Immunoreactivity was detected by the avidin-biotin peroxidase technique ${ }^{16-18}$. Sections were washed for $2 \times 10 \mathrm{~min}$ in PBS and incubated with 5\% normal goat serum (Sigma) for $30 \mathrm{~min}$ at room temperature with shaking. In the one-color immunoperoxidase experiments sections were then incubated for $48 \mathrm{~h}$ at $4^{\circ} \mathrm{C}$ with rabbit polyclonal antisera against the residues 1-24 of the bovine FGF-2 (Sigma), or also against a cow S100ß (Dakopatts, Denmark).

The antibodies were diluted (1:1500) in PBS containing $0.5 \%$ Triton X-100 (Sigma) and $1 \%$ bovine serum albumin (Sigma). The sections were washed again in PBS (2x10 min) and incubated with biotinylated goat anti-rabbit immunoglobulins diluted 1:250 (Vector, U.S.A.) for $2 \mathrm{~h}$. After rinsing in PBS, they were incubated with an avidin-biotin peroxidase complex (both diluted 1:100, Vectastain, Vector) for $90 \mathrm{~min}$. Immunoreactivity was visualized using 3-3'-diaminobenzidine tetrahydrocloride (DAB, Sigma) as a chromogen and $\mathrm{H}_{2} \mathrm{O}_{2}(0.05 \%$, v/v, Sigma $)$ for $8 \mathrm{~min}$. The anti-cow S100 was a purified immunoglobulin fraction from rabbit antiserum; it reacts with $\mathrm{S} 100 \alpha$ and $\mathrm{S} 100 \beta$ in many species including rat (Dakopatts).

Furthermore, two-color immunoperoxidase was used for further evaluation of the simultaneous detection of the FGF-2 and S100ß immunoreactivities. Briefly, FGF-2 immunostaining of the polyclonal bovine and rat FGF-2 antisera was performed as described above. Following the DAB reaction, the sections were rinsed several times in PBS and incubated over $48 \mathrm{~h}$ at $4{ }^{\circ} \mathrm{C}$ with the rabbit polyclonal $\mathrm{S} 1003$ antiserum (diluted 1:400). After several more rinses in PBS, they were incubated with biotinylated goat anti-rabbit immunoglobulin (diluted 1:200, Vector) for $1 \mathrm{~h}$ at room temperature, rinsed again in PBS, incubated with the avidin-biotin solution (both diluted 1:100, Vectastain, Vector) for $45 \mathrm{~min}$ at room temperature, and stained for $10 \mathrm{~min}$ using $0.05 \%$ 4-chloro-naphthol (Sigma) as a chromogen and $0.05 \%$ (v/v) $\mathrm{H}_{2} \mathrm{O}_{2}$ (Sigma). The sections were rinsed in PBS and cover-slipped in a glycerol phosphate buffered medium. This procedure gave a brownish color to the FGF-2 immunoreactivities and a bluish color to the S100ß immunoreactivity. The sections were analyzed and photographed with an AX70 Olympus photomicroscope (U.S.A).

As controls, adjacent sections were incubated in the absence of either the primary or secondary antibodies in the one- and two-color immunohistochemical procedures. Some sections were also incubated with the solvent of the avidin-biotin solution.

\section{Results}

\section{FGF-2 and S100ß in the cultured Schwann cells}

Immunocytochemistry demonstrated the presence of a strong labeling of S100ß in the cytoplasm of the cultured Schwann cells (Figure 2A). All Schwann cells in the culture stained for S100ß. Cultured cells were confluent and occupied the majority of the spaces in the plate surface as seen in the picture of phase contrast microscopy (Figure 2A,C). Confluent Schwann cells possessed a round to elliptic shape with 2 long well visible processes (Figure 2A). Moreover, FGF-2 immunoreactivity was also found in the majority of confluent cultured Schwann cells (Fig 2B). 

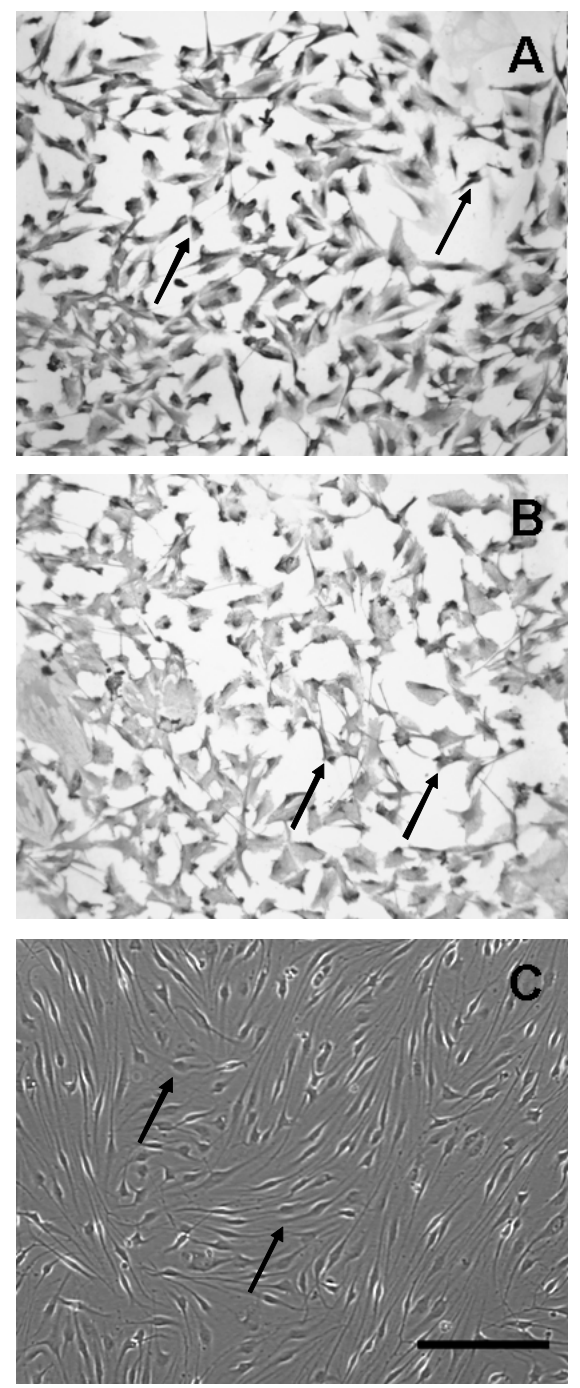

FIGURE 2 - Microphotographs of confluent cultured Schwann cells immunolabelled for S100ß (A) and FGF-2 (B). Immunoperoxidase technique was applied using polyclonal antibodies to $S 100 ß$ and FGF-2. The DAB was used as a chromogen. In panel $C$ we see Schwann cells photographed under phase contraste microscopy. The Schwann cells were obtained from the rat sciatic nerve. Bars: $20 \mu \mathrm{m}$

\section{FGF-2 S100}

\begin{tabular}{l|l}
$18 k D A$ & $10 k D A$
\end{tabular}

FIGURE 3 - The bands FGF-2 (left panel) and S100ß (right panel) proteins detected in cultured Schwann cells by means of Western blot technique. The Schwann cells were obtained from the rat sciatic nerve. The FGF-2 and S100ß bands were about $18 \mathrm{kDA}$ and $10 \mathrm{kDA}$, respectively.
Moreover, the Western blot technique revealed the band of the FGF-2 protein in the homogenized cultured Schwann cells (Figure 3). The analysis of the position of the band of the FGF-2 signal revealed a molecular weight of $18 \mathrm{kDA}$. Furthermore, the Western blot method also showed the band of the $\mathrm{S} 100 \mathrm{~B}$ protein in the homogenized cultured Schwann cells (Figure 3). The analysis of the position of the band of the S100ß signal revealed a molecular weight of 10kDA.

FGF-2 and S100ß in the satellite cells and Schwann cells in vivo and the effects of the sciatic nerve axotomy

Two-color immunoperoxidase method for simultaneous detection of FGF-2 and S100ß demonstrated the presence of a brownish color FGF-2 labeling in the bluish color S100ß immunostained satellite cells of the DRG and also in the bluish color S100ß immunostained Schwann cells of the sciatic nerve of the rat (Figure 4A,D).

The S100ß immunoreactive satellite cells of the axotomized DRG showed larger cytoplasm and accumulated increased amount of the FGF-2 immunoreactivity when compared to the contralateral unoperated side (Figure 4C,D). Moreover, the larger reactive satellite cells of the axotomized DRG formed ring like structures around the DRG neurons particularly those of larger size. Furthermore, the S100ß immunoreactive Schwann cells of the proximal stump of the axotomized sciatic nerve also accumulated increased amount of the FGF-2 immunoreaction product when compared to the contralateral unoperated side (Figure 4A,B).

Control sections of the DRG and nerves incubated with FGF-2 pre-adsorbed antibody showed no immunoreaction (not shown). Sections incubated with the solvent for the primary FGF-2 and $\mathrm{S} 100 ß$ antibodies, secondary antibody, or for avidin-biotin also showed no reaction.

\section{Discussion}

S100ß immunoreactive satellite cells surrounding the sensory neurons of the DRG indicate a functional interactive relationship. Sensory neurons of DRG are surrounded by satellite cell cytoplasmic expansions linked by gap junctional communications ${ }^{19}$. This morphological aspect further emphasizes the existence of a paracrine regulation, involving satellite glia and sensory neuron in the DRG. Moreover, sciatic nerve Schwann cells are also stained for S100ß immunoreactivity thus being an important histological marker to identify those cells. As described for the satellite cells/neuronal cell bodies of rat DRG, the Schwann cells also surround motor and sensory peripheral fibers forming the myelin sheath. Besides the functional importance of the myelin to neurons regarding the conduction of the action potential, the Schwann cells likely the satellite cells function as an important paracrine regulator of peripheral neurons at axonal level ${ }^{20,21}$. 
Regardless the common embryonic origin of the DRG satellite cells and the Schwann cells, it seems possible that those cells share the ability to monitor and to trigger physiological functions of their neighbor neurons. The paracrine trophic actions of satellite cells and the Schwann cells have been described during development of peripheral neurons ${ }^{7,19}$, and in the pos natal life regarding the maintenance and protection from injury-induced cell death $^{5}$.

The above consideration might explain the fact that satellite and Schwann cells may express similar types of molecules particularly in lesioned situations as described in the present analysis. The Schwann cells expressing FGF-2 and S100ß proteins were confirmed in the present analysis by means of immunocytochemistry and Western blot techniques.

The paracrine regulation among the satellite glia/Schwann cells and the lesioned peripheral neurons have been postulated because the neuronal disappearance coincides with the death of the up-regulated satellite cells after axotomy ${ }^{22}$. Moreover, axotomy also induces the hyperplasia of perineuronal satellite cells and triggers an incremented coupling in the lesioned $\mathrm{DRG}^{23}$. Likewise, Schwann cells react after axotomy both distally and proximally to the site of nerve injury. It seems possible that a trophic interaction of reactive satellite glia/Schwann cells and peripheral neurons is related to neuronal protection and/or nerve regeneration after axotomy ${ }^{2}$. It is likely that the satellite glia is also related to a continuous regulation of function and plasticity in peripheral sensory neurons as described for astrocytes in the lesioned central nervous system ${ }^{20,24-26}$.

Neurotrophic factors produced by satellite cells and Schwann cells are the key molecules in the mechanisms of peripheral neuronal development, maintenance, function and regeneration ${ }^{7,15}$.

S100ß immunoreactivity has been used as a marker for Schwann cells in vivo and in vitro ${ }^{27,28}$ and also for the satellite cells in vivo ${ }^{7}$. Moreover, the localization of $\mathrm{S} 1003$ protein in satellite cells of the DRG has been implicated in the maturation and trophic mechanisms of DRG neurons during development ${ }^{29}$.

It is known that FGF-2 is able to protect adult DRG neurons from lesion-induced sensory nerve cell death ${ }^{5}$. Moreover, FGF-2 immunoreactivity was demonstrated in cultured neuronal cells derived from DRG of chick and rat embryos, and also in developing rat DRG in vivo ${ }^{30,31}$.

We demonstrated here FGF-2 immunoreactivity in the satellite cells labeled by $\mathrm{S} 1003$ immunoreactivity respectively in the rat DRG and sciatic nerve by means of two-color immunohistochemistry. Our results are in line with previous descriptions that have identified FGF-2 mRNA signal in putative satellite cells of the rat DRG and Schwann cells by means of in situ hybridization $^{6}$. Moreover, we have described in a previous publication $^{7}$ increases of FGF-2 immunoreactivity in lumbar DRG and sciatic nerve of adult rat after axotomy. We have also showed increases of $\mathrm{S} 100 ß$ immunoreactivity in satellite cells of axotomized DRG by means of microdensitometric image analysis ${ }^{7}$. Two-color immunoperoxidase for FGF-2 detection in the S100ß positive satellite cells confirmed the increases of the FGF-2 product in reactive satellite glia of the axotomized DRG and also in the Schwann cells of proximal stump of axotomy of the sciatic nerve. An elevated number of Schwann cells expressing higher amounts of the FGF-2 immunoreactivity was also found in the proximal stump of the lesioned sciatic nerve. These observations confirmed and extended our previous analysis ${ }^{7}$.

Moreover, our results are in line and extend previous publications that have demonstrated increases of FGF-2 mRNA signal in putative satellite cells of DRG and in putative Schwann cells after axotomy of sciatic nerve ${ }^{32}$. Furthermore, increased FGF-2 mRNA signal was detected in macrophages and Schwann cells at the lesion site of axotomized sciatic nerve, as revealed by the cellular analysis of consecutive section ${ }^{33}$.

By means of $\mathrm{S} 100 ß$ immunohistochemistry, we identified increased amount of FGF-2 in activated DRG satellite cells and sciatic nerve Schwann cells after axotomy, cells that also expressed increased amount of S100ß protein, suggesting a possible interaction between those two molecules. Moreover, the increased S100ß and FGF-2 in reactive satellite cells of axotomized DRG and lesioned sciatic nerve may also be associated with local neovascularization, gliogenesis and repair ${ }^{34}$ as well as to paracrine neuronal trophism and plasticity in remaining DRG peripheral motor neurons.

\section{Conclusion}

The changes of FGF-2 and S100ß in activated satellite cells and Schwann cells of axotomized DRG and sciatic nerve respectively, open up the possibility for interactions between those molecules, a possible mechanism that should be investigated in the trophic/repair regulation of lesioned peripheral nervous system, thus important in the restoration of the lesioned nerves.

\section{References}

1. Zhou, X. F., Deng, Y. S., Chie, E., Xue, Q., Zhong, J. H., McLachlan, E. M., Rush, R. A., Xian, C. J. Satellite-cell-derived nerve growth factor and neurotrophin-3 are involved in noradrenergic sprouting in the dorsal root ganglia following peripheral nerve injury in the rat. Eur J Neurosci. 1999; 11(5): 1711-22.

2. Raginov, I. S., Chelyshev, Y. A.,Shagidullin, T. F. Interaction of sensory neurons and satellite cells during stimulation of nerve regeneration. Neurosci Behav Physiol. 2004; 34(1): 79-81.

3. Chadi, G., Fuxe, K. Analysis of trophic responses in lesioned brain: focus on basic fibroblast growth factor mechanisms. Braz J Med Biol Res. 1998; 31(2): 231-41.

4. do Carmo Cunha J, de Freitas Azevedo Levy B, de Luca BA, de Andrade MS, Gomide VC, Chadi G. Responses of reactive astrocytes containing S100beta protein and fibroblast growth factor- 2 in the border and in the adjacent preserved tissue after a contusion injury of the spinal cord in rats: implications for wound repair and neuroregeneration. Wound Repair Regen. 2007; 15(1):134-46.

5. Otto, D., Unsicker, K., Grothe, C. Pharmacological effects of nerve growth factor and fibroblast growth factor applied to the transectioned sciatic nerve on neuron death in adult rat dorsal root ganglia. Neurosci Lett. 1987; 83(1-2),156-60.

6. Grothe, C., Meisinger, C., Hertenstein, A., Kurz, H., Wewetzer, K. Expression of fibroblast growth factor- 2 and fibroblast growth factor receptor 1 messenger RNAs in spinal ganglia and sciatic nerve: regulation after peripheral nerve lesion. Neuroscience. 1997;76(1):123-35.

7. Levy Bde F, Cunha Jdo C, Chadi G. Cellular analysis of S100Beta and fibroblast growth factor-2 in the dorsal root ganglia and sciatic nerve of rodents. focus on paracrine actions of activated satellite cells after axotomy. Int J Neurosci. 2007; 117(10):1481-503.

8. Azmitia, E. C., Dolan, K., Whitaker-Azmitia, P. M. S-100B but not NGF, EGF, insulin or calmodulin is a CNS serotonergic growth factor. Brain Res. 1990;516(2), 354-6. 
9. Chadi, G., Rosen, L., Cintra, A., Tinner, B., Zoli, M., Pettersson, R. F., Fuxe, K. Corticosterone increases FGF-2 (bFGF) immunoreactivity in the substantia nigra of the rat. Neuroreport. 1993;4(6):783-6.

10. Grothe, C., Nikkhah, G. The role of basic fibroblast growth factor in peripheral nerve regeneration. Anat Embryol (Berl). 2001;204(3):171-7. 11. Huang, Y. L., Ding, M, Hansson, H. A. Dorsal root ganglion nerve cells transiently express increased immunoreactivity of the calciumbinding protein S-100beta after sciatic nerve transection. Brain Res. 1998;785(2):351-4.

12. Li Q, Ping P, Jiang H, Liu K. Nerve conduit filled with GDNF genemodified Schwann cells enhances regeneration of the peripheral nerve. Microsurgery. 2006;26: 116-121.

13. Morrissey TK, Kleitman N, Bunge RP. Isolation and functional characterization of Schwann cells derived from adult peripheral nerve. J Neurosci. 1991;11(8):2433-42.

14. Chadi G, Silva C, Maximino JR, Fuxe K, da Silva GO. Adrenalectomy counteracts the local modulation of astroglial fibroblast growth factor system without interfering with the pattern of 6-OHDA-induced dopamine degeneration in regions of the ventral midbrain. Brain Res. 2008;23;1190:23-38.

15. Dallo JG, Reichert BV, Valladão Júnior JB, Silva C, Luca BA, Levy Bde F, Chadi G. Differential astroglial responses in the spinal cord of rats submitted to a sciatic nerve double crush treated with local injection of cultured Schwann cell suspension or lesioned spinal cord extract: implications on cell therapy for nerve repair. Acta Cir Bras. 2007;22(6):485-94.

16. Gomide, V. C., Chadi, G. Prenatal ethanol enhances rotational behavior to apomorphine in the 24-month-old rat offspring with small striatal lesion. Neurotoxicol Teratol. 2004;26(3):417-27.

17. Rodrigues, R. W., Gomide, V. C., Chadi, G. Astroglial and microglial activation in the wistar rat ventral tegmental area after a single striatal injection of 6-hydroxydopamine. Int J Neurosci. 2004;114(2):197-216.

18. Andrade MS, Hanania FR, Daci K, Leme RJ, Chadi G. Contuse lesion of the rat spinal cord of moderate intensity leads to a higher time-dependent secondary neurodegeneration than severe one. An open-window for experimental neuroprotective interventions. Tissue Cell. 2008;40(2):143-56. 19. Sakuma, E., Wang, H. J., Asai, Y., Tamaki, D., Amano, K., Mabuchi, Y., Herbert, D. C., Soji, T. Gap junctional communication between the satellite cells of rat dorsal root ganglia. Kaibogaku Zasshi. 2001;76(3):297-302.

20. Gomide, V. C., Chadi, G. The trophic factors S-100beta and basic fibroblast growth factor are increased in the forebrain reactive astrocytes of adult callosotomized rat. Brain Res. 1999;835(2):162-74.

21. Cerutti, S. M., Chadi, G. S100 immunoreactivity is increased in reactive astrocytes of the visual pathways following a mechanical lesion of the rat occipital cortex. Cell Biol Int. 2000;24(1):35-49.
22. Hu, P., McLachlan, E. M. Selective reactions of cutaneous and muscle afferent neurons to peripheral nerve transection in rats. J Neurosci. 2003;23(33):10559-67.

23. Pannese, E., Ledda, M., Cherkas, P. S., Huang, T. Y., Hanani, M. Satellite cell reactions to axon injury of sensory ganglion neurons: increase in number of gap junctions and formation of bridges connecting previously separate perineuronal sheaths. Anat Embryol (Berl). 2003;206(5):337-47. 24. Chadi, G., Cao, Y., Pettersson, R. F., Fuxe, K. Temporal and spatial increase of astroglial basic fibroblast growth factor synthesis after 6-hydroxydopamine-induced degeneration of the nigrostriatal dopamine neurons. Neuroscience. 1994;61(4):891-910.

25. Lee, S. L., Kim, J. K., Kim, D. S., Cho, H. J. Expression of mRNAs encoding full-length and truncated TrkB receptors in rat dorsal root ganglia and spinal cord following peripheral inflammation. Neuroreport. 1999;10(13):2847-51.

26. Gomide, V. C., Silveira, G. A., Chadi, G. Transient and widespread astroglial activation in the brain after a striatal 6-OHDA-induced partial lesion of the nigrostriatal system. Int J Neurosci. 2005;115(1):99-117.

27. Wewetzer, K., Grothe, C., Christ, B., Seilheimer, B. Identification and characterization of differentiation-dependent Schwann cell surface antigens by novel monoclonal antibodies: introduction of a marker common to the non-myelin-forming phenotype. Glia. 1997;19(3):213-26. 28. Vega, J. A., del Valle-Soto, M. E., Calzada, B., Alvarez-Mendez, J. C. Immunohistochemical localization of S-100 protein subunits (alpha and beta) in dorsal root ganglia of the rat. Cell Mol Biol. 1991;37(2):173-81. 29. Bhattacharyya, A., Oppenheim, R. W., Prevette, D., Moore, B. W., Brackenbury, R., Ratner, N. S100 is present in developing chicken neurons and Schwann cells and promotes motor neuron survival in vivo. $\mathrm{J}$ Neurobiol. 1992;23(4):451-66.

30. Janet, T., Grothe, C., Pettmann, B., Unsicker, K., Sensenbrenner, M. Immunocytochemical demonstration of fibroblast growth factor in cultured chick and rat neurons. J Neurosci Res. 1988;19(2):195-201.

31. Weise, B., Janet, T., Grothe, C. Localization of bFGF and FGF-receptor in the developing nervous system of the embryonic and newborn rat. $\mathrm{J}$ Neurosci Res. 1993;34(4):442-53.

32. Meisinger, C., Grothe, C. Differential regulation of fibroblast growth factor (FGF)-2 and FGF receptor $1 \mathrm{mRNAs}$ and FGF-2 isoforms in spinal ganglia and sciatic nerve after peripheral nerve lesion. J Neurochem. 1997;68(3):1150-8.

33. Grothe, C., Meisinger, C., Claus, P. In vivo expression and localization of the fibroblast growth factor system in the intact and lesioned rat peripheral nerve and spinal ganglia. J Comp Neurol. 2001;434(3):342-57. 34. Selinfreund, R. H., Barger, S. W., Pledger, W. J., Van Eldik, L. J. Neurotrophic protein S100 beta stimulates glial cell proliferation. Proc Natl Acad Sci U S A. 1991;88(9):3554-8.

\section{Correspondence:}

Gerson Chadi, M.D., Full Professor

Department of Neurology

University of São Paulo

Av. Dr. Arnaldo, 455 2nd floor, room 2119

01246-903 - São Paulo.Brazil

Phone: 5511 3061-7460

gerchadi@usp.br
Conflict of interest: none Financial source: FAPESP and CNPq

\footnotetext{
How to cite this article

Duobles T, Lima TS, Levy BF, Chadi G. S100ß and fibroblast growth factor-2 are present in cultured Schwann cells and may exert paracrine actions on the peripheral nerve injury

Acta Cir Bras. [serial on the Internet] 2008 Nov-Dec; 23(6). Available from URL: http://www.scielo.br/acb
}

*Color figures available from: http://www.scielo.br/acb 